より，個々の照射時にしない医師や技師も照射部位を正 雅に知るととが出来るため治療後の患者の診断，治療上 て机いて非常に有益である。

19. 放医研陽子線治療について一治療計画について 放射線医学総合研究庍

○网本 良・岡崎 笑・坂下邦雄 熊谷和正 - 柴山园一

放射線により治療を行う場合，体内の腫愓だけに放射 線を照射するととができれば，周りの正常組織の障害を 軽減するてとがきる。放医研サイクロトロンから得ら れる $70 \mathrm{MeV}$ 陽子線は, その線量分布と物理的特性を利 用し，高線量でかつ腫禓だけに照射するてとができる。 また，放矦研ては Spot Scanning 乙いう照射法を用い ている. つまり $1 \mathrm{~cm}$ 正方形を単位として, 不整形照射 野及び線量分布を得ることにより自由な照射野が得られ る. とのような照射法により，治療計画はこニコンピ 一夕NOVA3 を用い, CT 像等を利用し治療医の指示す る陽子線治蟟計画用紙にもとづして行われる.

\section{0. 治療計画の最適化処理について}

横浜打立大学医学部病院 中央放射線部

O大島 弘・传々木健二

放射線治療計画システム（VARIAN-RO 7) による計 算結果とフィルム法, TLD 法による線量分布を比較検 討した。“最適化処理”により対話形式又は最適化過程 を利用した自動方式で治療計画の目的でる病栄部と匀 一な線量を与え周团の健常組織に対して低線量（照射制

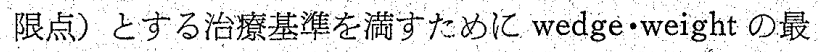
良の組み合せを選択するととができる。この場合線量分 布の計算結果の良否が問題となるがその結果は十分に満 足できるもので成り臨床に応用できると考えられる.

照射方法の設定にはある程度の経験を必要とするか RO 7 の最適化处理を行うことにより短時間で最邉な計 画が得られる。

21. パーソナルコンピュータによる放射線治療へのシミ ニレーション

国立高崎病院 放射線科 ○田胡雄司 放射線測定に执して, 測定器からのデータの読み取り, テンキーからの大力は多くの時間と学力をついやすとと がある.パーコンの活用の一試案として，測定处理の高 速化・省力化を試みた。平担度チェ，カのアナログ出力 をテータ収集回路でA-D 変喚し, パーコンに入つさせ 補正計覚処理のシそレーションを行った.ゲームなど遊 ひ中心と合われるパーコンが工夫次第で我々，技術者の 強力なツールとなる,パーコンを導入しむえすれぱ, 誰
でも骨も抽ずに使用出来るかというと，とうでない。 との程度の初歩的なとしである程度の川ード, けト の技術と根気と熱意加必要である。しれらの条件がそろ えば強才なッールとなるといえる.

\section{NEC-VARIAN $18 \mathrm{MeV} リ こ ア ッ ク$ 治療システム}

信州大学医学部附属病院 中央放射線部 ○竹村克人・宫沢正則·丸山 清

NECVARIAN $18 \mathrm{MeV}$ リアックを中心とした放射 線治療システムについて, NELAC-1018 型り $\mathrm{X}$ 線，電子線の基礎データの検討と，THERAC-III/C18 自動制御及び治療討画システムについて検討した。 10 MVX線についての測定結果は他機種のそれと大差ない 加，電子線てついては特徽的であった. THERAC シ ス テムについては特につフトウェアの開発とCT 情報の治 療計画への応用を計るため,ディスクと MT を組込み, 検討を始めた，各社 CT 画像の MTを利用し，データ をディスクに収め画像処理をして体輪鄭の描出をし， 線 量分布計算ができるようにした。

\section{RI 施設における細菌測定について}

群馬大学䀢学部附属病院 中央放射線部

○細野紀一・佐藤貞男・南雲堯生 松原国夫・白石明久・會石政彦

放射性医薬品使用管理の一端を目的とし + 空気中落下 細菌測定を武みた。測定場所は，患者に RI 注入する

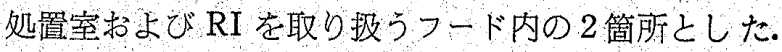
測定回数は 1 日に 3 回 ( 9 時，12時，15時) て日を変え て6日間，合計18回測定した.その結果，各菌種の検出 回数は，処䈯宝では18回測定中， $\mathrm{G}+$ 球菌10國， $\mathrm{G}+$ 杆 菌 3 回， $\mathrm{G}$-球菌 2 回, $\mathrm{G}$-杆菌 1 回, フード内では 18 回測定中, $\mathrm{G}+$ 球菌 12 回, $\mathrm{G}+$ 杆菌 8 回, $\mathrm{G}$-杆菌 3 回 でめった．経時的変化ては，㚭䈯室，フード内しもに， 9 時の測定時に落下囷の数汃最も多し傾向が認められた. 活染，被曝のみならず然菌操作にも，注意が必要である と思われた。

\section{4. クラムシェルコリメータの性能}

群馬大学医学部附属病院 中央放射線部 $\bigcirc$ 五十蔵均・高橋一宇，浦野晴哉 久保田博 $\cdot$ 宮沢康志 $\cdot$ 大竹英則 佐藤貞夫

多核種使用に伴ない,コリメーターの種類も多く取扱 い上非常に学力を費すか，今回当院において，手軽に脱 着できる低エネルギー用コリメータ（クラムシエル）が 導入されたので均一性を内心とした性能評価を話みた。 心蔵核医学が進むにつれて，1回の検查厄コリxータの 